\title{
Eksistensi Pelaksanaan Pidana dan Pemidanaan Pidana Tutupan
}

\author{
Saud Tua Marpaung \\ TNI-AD \\ saudtuamarpaung90@gmail.com
}

\begin{abstract}
Abstrak
Dasar hukum pidana tutupan yaitu UU No. 20 Tahun 1946 (Berita RI Tahun II Nomor 24) dimaksudkan untuk menggantikan pidana penjara dalam hal Hakim mengadili orang yang melakukan tindakan pidana dengan terdorong oleh maksud yang patut dihormati dan diatur pula dalam PP No. 8 Tahun 1948 yang mana menentukan tentang Rumah Tutupan sebagai pelaksanaan dari pada UU No. 20 Tahun 1946 mengenai cara pelaksanaan, buat sementara waktu, berhubungan dengan keadaan. Rumusan masalah yaitu bagaimana relevansi sistem penerapan pidana tutupan dikaitkan dengan Pasal 10 KUHP dan Pasal 6 KUHPMiliter terhadap pidana penjara dan apakah penerapan pidana tutupan masih efektif diberlakukan dalam sistematika KUHPidana Indonesia dikaitkan masih ditempatkannya pidana tutupan dalam RUU KUHPidana? Tujuan penelitian menjelaskan tentang relevan atau tidaknya sistem penerapan pidana tutupan di Indonesia dengan sudah adanya pidana penjara dan pidana kurungan dan menjelaskan penerapan pidana tutupan masih efektif diberlakukan dalam sistematika KUHPidana Indonesia dikaitkan masih ditempatkannya pidana tutupan dalam RUU KUHPidana. Kegunaan penelitian memberikan suatu pokok bahasan bersama pakar hukum dan masyarakat umum tentang arti pidana tutupan di Indonesia dan memberikan informasi pada pakar hukum serta masyarakat umum adanya pidana tutupan dalam pidana pokok yang diatur dalam KUHPidana. Metode penelitian yang penulis gunakan adalah metode penelitian normatif. Hasil Penelitian ini merupakan Penjatuhan Pidana Tutupan tidak lagi pernah diterapkan sampai dengan sekarang ini sejak pertama kali dijatuhkan pada pelaku peristiwa 3 Juli 1946, yang mana perkara tersebut diadili oleh Mahkamah Tentara Agung dalam tahun 1948 di Yogyakarta. Kesimpulan dari penelitian ini ialah Pidana tutupan agar tetap dapat dipertahankan dalam KUHPidana Indonesia kedepan, namun bukan hanya diterapkan kepada pelaku tindak pidana/delik politik saja namun dapat juga diterapkan kepada pelaku tindak pidana lainnya baik itu tindak pidana umum, militer maupun tindak pidana khusus lainnya.
\end{abstract}

Kata Kunci: Eksistensi, pidana dan pemidanaan, pidana tutupan.

\section{The Existence of Implementation Criminal and Criminal Criminal Closure}

\begin{abstract}
The legal basis for criminal cover is Law No. 20 of 1946 (RI News Year II Number 24) is intended to replace imprisonment in the case of a Judge adjudicate a person who commits a criminal act driven by an intention that deserves respect and is also regulated in PP No. 8 of 1948 which
\end{abstract}


determines the Closing House as the implementation of Law No. 20 of 1946 concerning how to implement, for a while, related to the situation. The formulation of the problem is how is the relevance of the system of the application of the criminal closure associated with Article 10 of the Criminal Code and Article 6 of the Indonesian Criminal Code against imprisonment and is the application of the criminal closure still effectively applied in the systematics of the Indonesian Penal Code related to the placement of criminal closure in the Criminal Code Bill? The purpose of this research is to explain whether the system of criminal closure is relevant or not in Indonesia with the existence of imprisonment and confinement and explains that the application of criminal closure is still effectively applied in the Indonesian Criminal Code systematics related to the placement of criminal closure in the Criminal Code Bill. The usefulness of the study provides a subject together with legal experts and the general public about the meaning of criminal cover in Indonesia and provides information to legal experts and the general public for the existence of criminal cover in the principal criminal regulated in the Criminal Code. The research method that I use is a normative research method. The result of this research is that the Criminal Enactment of Criminal Coverage has never been applied until now since it was first dropped on the perpetrators of the July 3, 1946 incident, in which the case was tried by the Supreme Army Court in 1948 in Yogyakarta. The conclusion of this research is the Criminal closure so that it can be maintained in the Indonesian Criminal Code in the future, but it is not only applied to perpetrators of criminal acts I political offenses, but can also be applied to other perpetrators of criminal acts, both general, military and other special criminal offenses.

Keywords: Existence, criminal and criminal, criminal closure.

\section{Pendahuluan}

Seperti diketahui bersama bahwa eksistensi adanya pelaksanaan pidana tutupan di Indonesia hampir tidak pernah terjadi lagi semenjak peristiwa 3 Juli 1946, sehingga muncul pertanyaan, apakah masih relevan penerapan pidana tutupan ini diberlakukan? Karena pelaksanaan pidana tutupan ini sulit ditemukan, artinya bahwa peristiwa terjadinya seseorang melakukan tindak pidana yang disebabkan terdorong oleh maksud yang patut dihormati hampir jarang ditemukan.

Adapun contoh kasus terjadi pada tahun 2013 didaerah Istimewa Yogyakarta tepatnya di Lembaga Pemasyarakatan Gebongan-Sleman, telah terjadi peristiwa penembakan oleh Serda Ucok dan kawan-kawannya, sehingga mengakibatkan empat (4) orang tewas, dikutip dari (Eko Huda Setyawan, "Eksekutor Cebongan: Setelah Tembak 4 Tahanan, Saya Gemetar": liputan6.com), yaitu peristiwa atau kasus penembakan di Lembaga 
Pemasyarakatan Cebongan, Sleman, Daerah Istimewa Yogyakarta pada 23 Maret 2013 oleh Serda Ucok dan kawan-kawan yang mengakibatkan tewasnya empat (4) orang didalam Lembaga Pemasyarakatan Cebongan sebagai akibat peristiwa Pada Selasa, 19 Maret 2013, pukul 02.30 terjadi pengeroyokan yang dilakukan oleh beberapa orang terhadap seorang sersan satu Kopassus Kandang Menjangan Kartasura bernama Heru Santosa di tempat hiburan Hugo's Cafe di Jalan Adisucipto, Depok, Sleman, Daerah Istimewa Yogyakarta Heru Santosa tewas dalam pengeroyokan tersebut (Eko Huda Setyawan, "Divonis, Kopassus Penyerang Lapas Cebongan Panen Dukungan": liputan6.com).

Peristiwa tersebut di atas, mendapatkan respon berbeda, ada yang memberikan apresiasi baik dari masyarakat khususnya warga Sleman, karena dianggap tindakan tersebut merupakan suatu tindakan pembenaran dengan alasan atas tindakan dari para pelaku telah menciptakan suatu keadaan menjadi aman bagi masyarakat. Namun demikian, peristiwa tersebut ada yang menganggap itu merupakan suatu tindak pidana murni karena telah mengakibatkan hilangnya nyawa orang lain. Hal ini telah diatur dalam KUHPidana dan KUHPMiliter dan para pelaku dari tindak pidana tersebut dikenakan sanksi pidana pokok dan KUHPMiliter yaitu Pidana Penjara.

Dalam kasus tersebut, Ketua Majelis Hakim yang bernama Joko Sasmito mengatakan bahwa terdakwa, Serda Ucok Tigor Simbolon, Serda Sugeng Sumaryanto dan Koptu Kodik dinyatakan bersalah karena telah melakukan tindak pidana berencana dan dinilai telah mencemarkan nama baik TNI serta menunjukkan suatu pemikiran yang sempit. Dan ketiga terdakwa tersebut divonis masing-masing yaitu Serda Ucok divonis 11 tahun, Serda Sugeng 8 tahun dan Koptu Kodik 6 tahun. Dengan adanya sanksi oleh hakim, maka ketiga terdakwa tersebut juga dipecat dari TNI

Selain contoh kasus tersebut di atas, ada contoh kasus lainnya, yaitu kepemilikan tanaman ganja dirumah, kasus ini terjadi di Kabupaten Sanggau Propinsi Kalimantan Barat. Latar belakang terjadinya kasus ini, yaitu pelaku menanam ganja disebabkan untuk pengobatan isterinya yang sedang sakit yang mengidap penyakit Syringomyelia. Penyakit tersebut salah satu penyakit langka 
dengan munculnya kista di sumsum tulang belakang. Pemilik ganja bernama Fidelis dan ditangkap aparat Badan Narkotika Nasional (BNN) Kabupaten Sanggau pada pertengahan bulan Februari 2017. Selama masa tersebut Fedelis tidak bisa lagi memberikan pengobatan kepada istrinya berupa ekstrak ganja yang saat itu menjadi satu-satunya harapan untuk bisa sembuh dan bertahan hidup. Pada hari Sabtu tanggal 25 Maret 2017 isteri Fedelis dinyatakan meninggal dunia di Rumah Sakit Umum Daerah (RSUD) M. Th. Djaman Kabupaten Sanggau disebabkan penyakit yang dideritanya tersebut. Yeni sang istri meninggalkan Fedelis dan keluarga terhitung masa penangkapan yaitu 32 hari di bui Rumah Tahanan Kabupaten Sanggau, yang mana setelahnya kondisi Yeni kembali menurun (Yohanes Kurnia Irawan, "Akhir Perjuangan Suami yang Obati Istrinya dengan Ganja, Fidelis Bebas dari Penjara”: kompas.com).

Dalam persidangan kasus ini, Jaksa Penuntut Umum (JPU), Fidelis sebagai terdakwa dikenakan 3 (tiga) pasal dakwaan berdasarkan UU No. 35 Tahun 2009 tentang Narkotika yaitu: Pasal 113 ayat (2), Pasal 111 ayat (2), dan Pasal 116 ayat (1). Bedasarkan pasal-pasal tersebut, bahwa terdakwa diantaranya telah memproduksi, menanam, memelihara, memiliki, dan tanpa hak, sehingga perbuatan ini dinyatakan perbuatan melanggar hukum, dengan ancaman pidana maksimal hukuman mati, dan pidana penjara 5 hingga 20 tahun.

Menelaah dalam peristiwa tersebut di atas menurut Penulis terdakwa Fidelis "tidak memiliki niat buruk untuk memperdagangkan ganja dan tidak merugikan orang lain", dan dapat penulis katakan bila Hakim jeli dan memahami akan pengetahuan terkait adanya UU No. 20 Tahun 1946 tentang Hukuman Tutupan, maka unsur dalam Pasal 2 ayat (1) dapat saja dijalankan oleh Majelis Hakim yaitu: "Dalam mengadili orang yang melakukan kejahatan, yang diancam dengan hukuman penjara, karena terdorong oleh maksud yang patut dihormati, hakim boleh menjatuhkan hukuman tutupan”. Di mana dalam hal ini menurut Penulis tindakan Fedelis adalah suatu tindakan karena "terdorong oleh maksud yang patut dihormati”. Namun dalam pelaksanaannya dengan alasan hukum harus ditegakkan, Fidelis tetap divonis penjara selama 8 (delapan) bulan dan denda sebesar Rp. 1.000.000.000,- (satu milyar rupiah) subsider 1 (satu) bulan 
penjara. Vonis Hakim tersebut terbilang berat, pasalnya Jaksa Penuntut Umum hanya menuntut Fidelis di penjara 5 (lima) bulan dan denda Rp. 800.000.000,(delapan ratus juta rupiah) subsider satu bulan penjara. Meski menanam ganja untuk mengobati istrinya, Hakim menilai Fedelis menyalahi Pasal 111 dan Pasal 116 Undang-Undang Nomor 35 Tahun 2009 tentang Narkotika. Berdasarkan fakta di persidangan, Hakim menilai yang memberatkan dasar putusan Fidelis adalah Pasal 116 ayat (1) dan (3) Undang-Undang Nomor 35 Tahun 2009 tentang Narkotika (Undang-Undang Republik Indonesia Nomor 35 Tahun 2009 tentang Narkotika, 2009). Untuk itu Penulis meneliti dengan rumusan masalah yang mungkin dapat menjadi pemikiran bersama.

Berdasarkan latar belakang di atas maka peneliti merumuskan beberapa permasalahan yang ada, yakni :

a. Bagaimana relevansi sistem penerapan pidana tutupan dikaitkan dengan pasal 10 KUHPidana dan pasal 6 KUHPMiliter terhadap pidana penjara?

b. Apakah penerapan pidana tutupan masih efektif diberlakukan dalam sistematika KUHPidana Indonesia dikaitkan masih ditempatkannya pidana tutupan dalam RUU KUHPidana?

Penelitian ini menggunakan metode analisis yuridis empiris. Penelitian dilakukan dengan memadukan bahan-bahan sumber hukum berupa peraturan perundang-udangan dengan mengobservasi peristiwa empiris yang terjadi. Sumber hukum yang digunakan dalam penelitian ini.

\section{Pembahasan}

I. Relevan Atau Tidaknya Sistem Penerapan Pidana Tutupan Di Indonesia Dengan Sudah Adanya Pidana Penjara

Penerapan pidana tutupan di Indonesia telah diatur dan sebagai dasar hukum pidana tutupan ini dapat dilihat pertama-tama pada UU No. 20 Tahun 1946, pada Konsiderans dikatakan sebagai berikut :

“....perlu mengadakan hukuman pokok baru, selain daripada hukumanhukuman tersebut Pasal 10a KUHP dan Pasal 6a KUHPM (1).” 
Kemudian dalam Pasal 1 disebutkan : "Selain daripada hukuman pokok tersebut Pasal 10a KUHP dan Pasal 6a KUHPM ada hukuman pokok baru, yaitu hukuman tutupan, yang menggantikan hukuman penjara dalam hal : diutur dalam Pasal 2 ayat (1) dan ayat (2), yang menyatakan bahwa dalam mengadili pelaku kejahatan dengan ancaman pidana penjara, dan disebabkan terdorong oleh maksud yang patut dihormati, maka hakim boleh menjatuhkan hukuman tutupan, namun hal ini tidak berlaku jika hakim berkeyakinan bahwa hukuman penjara merupakan lebih tepat.

Masih dalam UU No. 20 Tahun 1946 tentang Hukuman Tutupan, dalam Pasal 4 mengatur bahwa: "Semua peraturan tentang pidana penjara juga berlaku bagi pidana tutupan, sepanjang tidak bertentangan dengan sifat atau peraturan khusus tentang pidana tutupan".

Adapun yang dimaksud pidana penjara, yaitu dipenjara seumur hidup atau selama kurun waktu tertentu, Waktu tertentu paling pendek satu hari dan paling lama lima belas tahun berturut-turut, dan jika ada dua pilihan antara pidana mati dan pidana seumur hidup, hakim boleh menjatuhkan pidana untuk 20 tahun berturut-turut, dan pidana penjara selama waktu tertentu, atau antara pidana penjara seumur hidup dan pidana penjara selama waktu tertentu; begitu juga dalam hal batas lima belas tahun dilampaui sebab tambahanan pidana karena perbarengan, pengulangan atau karena ditentukan dalam Pasal 52. Pidana penjara selama waktu tertentu sekali-kali tidak boleh melebihi dua puluh tahun (Undang-Undang RI Nomor 1 Tahun 1946 jo Undang-Undang RI Nomor 73 Tahun 1958).

Dengan demikian bahwa relevan atau tidaknya kaitan penerapan Pidana Tutupan dengan Pidana Pokok lainnya yaitu Pidana Penjara dan Pidana Kurungan, maka hal ini dapat dilihat dalam peristiwa Kudeta pada tanggal 3 Juli 1946. Dilakukan oleh para tokoh pejuang Republik (Soegiri. dkk, 1976 : 71-76), yakni : "Mayor Jenderal Soedarsono, Mr. Mohamad Yamin, Mr. Achmad Soebardjo, dan Mr. Iwa Kusuma Sumantri dkk, yang didakwakan Pasal 107 KUHP jo Pasal 53" (dalam UU RI No. 1 Tahun 1946 jo UU RI Nomor 73 Tahun 1958) pasal tersebut menyatakan : 


\section{Pasal 107 :}

(1) Makar dengan maksud untuk menggulingkan pemerintah, diancam dengan pidana penjara paling lama lima belas tahun.

(2) Para pemimpin dan pengatur makar tersebut dalam ayat (1), diancam dengan pidana penjara seumur hidup atau pidana penjara sementara paling lama dua puluh tahun.

\section{Pasal 57}

(1) Dalam hal pembantuan, maksimum pidana pokok terhadap kejahatan, dikurangi sepertiga.

(2) Jika kejahatan diancam dengan pidana mati atau pidana penjara seumur hidup, dijatuhkan pidana penjara paling lama lima belas tahun.

(3) Pidana tambahan bagi pembantuan sama dengan kejahatannya sendiri.

(4) Dalam menentukan pidana bagi pembantu, yang diperhitungkan hanya perbuatan yang sengaja dipermudah atau diperlancar olehnya, beserta akibat-akibatnya.

Dengan demikian secara teoritis bahwa dakwaan ini dapat dipahami, meskipun secara praktek sulit dimengerti. Karena dalam Pasal 53 berlaku untuk semua tindak pidana, sedangkan dalam Pasal 87 dikatakan ada makar untuk melakukan suatu perbuatan, dan apabila ada niat untuk itu dari adanya permulaan pelaksanaan, sebagaima yang dimaksud dalam Pasal 53 tersebut.

Jadi penulis beranggapan dalam hal mengapa hakim menjatuhkan hukuman pada para tertuduh dengan pidana tutupan adalah penulis lebih setuju dengan pendapat Sudarto yang mengatakan bahwa seandainya tokoh politik ini sampai dijatuhi pidana penjara, padahal tokoh ini sebenarnya adalah kawan seperjuangan dari pemimpin-pemimpin Republik pada waktu itu, maka jelas bahwa tokoh ini tidak dapat disamakan dengan penjahat biasa, seperti pencuri, pembunuh, dan lain sebagainya. Maka dari itu ada jenis pidana yang khusus bagi mereka (S.R. Sianturi, 2013 : 113).

Terkait peristiwa tersebut diatas maka penulis berpendapat pada era saat ini relevansi pidana tutupan dalam penerapannya dapat saja disalahkan gunakan oleh beberapa kalangan penguasa lewat beberapa pakar hukum sebagai metode penyelamat dengan alasan karena terdorong oleh maksud yang patut dihormati dengan merujuk peristiwa 3 Juli 1946, karena menurut penulis sangatlah wajar 
pada saat itu dimana memang masih bergejolaknya Republik dan masih adanya keeratan hubungan para tokoh pejuang saat itu sehingga diputuskanlah pidana tutupan bagi mereka demi menjaga kehormatan dan tujuan mulia.

Sampai dengan sekarang ini pidana tutupan baru sekali pernah dijatuhkan oleh hakim kepada pelaku tindak pidana yaitu pada tanggal 27 Mei 1948 terhadap pelaku peristiwa kudeta 3 Juli 1946. Kudeta 3 Juli 1946 dilakukan oleh para tokoh pejuang Republik pada saat itu, yakni: Mayor Jenderal Soedarsono, Mr. Mohamad Yamin, Mr. Achmad Soebardjo, Mr. Iwa Kusuma Sumantri dan kawan-kawan, serta pasal yang didakwakan adalah pasal 107 KUHPidana jo pasal 53 KUHPidana.

Secara teoritis dakwaan ini dapat dipahami, namun dalam prakteknya sukar dimengerti. Mengapa, sebab pasal 53 adalah pasal yang berlaku untuk semua tindak pidana. Dalam praktek makar itu baru merupakan niat, belum adanya permulaan pelaksanaan karena dalam makar tidak dipermasalahkan tidak selesainya tindakan karena kehendak sendiri (S.R. Sianturi, 2013:113). Kejahatan yang terbukti dilakukan oleh tertuduh I dan II adalah memimpin percobaan untuk merobohkan pemerintahan yang sah, sedangkan tertuduh lainnya ialah percobaan untuk merobohkan pemerintahan yang sah. Untuk itu para tertuduh dipidana dengan pidana tutupan yang berkisar antara 4 tahun dan 2 tahun. (S.R. Sianturi, 2013:114)

Adapun susunan majelis hakim pada saat itu yang mengadili mereka di Mahkamah Tentara Agung adalah sebagai berikut:

1. Ketua $\quad$ : Mr. Dr. Kusuma Atmaja

2. Anggota : Mr. Wirjono Prodjodikoro

3. Anggota : Letnan Jenderal Sukono Djonopratiknyo

4. Anggota : Mayor Jenderal Sukarnen Martodikusumo

5. Anggota : Mayor Jenderal Didi Kartasasmita

6. Panitera : Mr. Subekti

7. Jaksa Agung : Mr. Tirtawinata

Mahkamah Tentara Agung saat itu dibentuk berdasarkan Aturan Pengadilan Tentara oleh Presiden Republik Indonesia, sesuai dengan keadaan dan 
mengingat Maklumat Wakil Presiden Republik Indonesia tanggal 16 Oktober 1945 Nomor X, dalam Interlocutor vonnis Mahkamah Tentara Agung Republik Indonesia di Yogyakarta tanggal 4 Maret 1948 dan dikuatkan dengan putusan akhir (end vonnis) Mahkamah Tentara Agung tanggal 27 Mei 1948 dengan tegas dinyatakan bahwa Pemerintah Republik Indonesia yang ada saat itu dan segala badan-badan, begitu pula Mahkamah Tentara Agung yang diserahi mengadili perkara para terdakwa Sudarsono dan kawan-kawan adalah sah adanya. Yang ditunjuk dalam majelis hakim terdiri dari 2 (dua) orang sipil dan 3 (tiga) perwira militer. (S.R. Sianturi, 2013:115) Jika diperhatikan tanggal dibuatnya UndangUndang Nomor 20 Tahun 1946 yaitu pada tanggal 31 Oktober 1946, maka jelas bahwa Undang-Undang ini dibuat setelah terjadinya peristiwa atau setelah terjadinya tindak pidana yang dilakukan pada peristiwa 3 Juli 1946. (UndangUndang Republik Indonesia Nomor 20 Tahun 1946 tentang Hukuman Tutupan). Adapun Peraturan Pemerintah Nomor 8 Tahun 1948 dibuat pada tanggal 4 Mei 1948 yaitu pada saat peristiwa 3 Juli 1946 akan diajukan kesidang pengadilan. (Peraturan Pemerintah Nomor 8 Tahun 1948 tentang Rumah Tutupan) Berarti dengan demikian rumah tutupan baru berusia lebih kurang 3 (tiga) minggu pada saat dijatuhkannya pidana tutupan (27 Mei 1948) kepada para pelaku kudeta peristiwa 3 Juli 1946.

Masalah lain yang timbul adalah apakah yang disebut tindak pidana politik dikarenakan peristiwa di atas. Beberapa pakar hukum pidana Indonesia berpendapat peristiwa tersebut terjadi karena suasana politik saat itu. Ada yang menafsirkan tindak pidana politik sebagai usaha untuk meruntuhkan pemerintah yang sah secara terorganisasikan (Organized effort to overthrow the existing government) tetapi ada juga yang memperluas pengertian ini sampai kepada perbuatan yang dapat mengganggu politik sosial (social politic) yaitu setiap usaha dari pemerintah untuk meningkatkan kesejahteraan bangsanya, dalama arti lain perbuatan yang dapat mengganggu pembangunan. (Edi Setiadi dan Dian Andriasari, 2013:9)

Tahun 1963 pernah diciptakan Undang-Undang terkait tindak pidana Subversif yaitu Undang-Undang Nomor 11/PNPS/tahun 1963 tentang 
pemberantasan kegiatan Subversif namun telah dihapuskan didasarkan atas amanat Ketetapan MPR nomor X tahun 1998 disertai penyisipan pasal-pasal baru dalam KUHPidana yang menyangkut delik ideologi yaitu pasal-pasal 107a, 107b, 107c, 107e, 107f. Dari hal ini yang menarik dikaji adalah mengenai dasar hukum yang digunakan ketika itu untuk mengadili tindak pidana subversif dianggap tidak mempunyai landasan yuridis, sosiologis dan praktis yang memadai. Dimana secara yuridis bentuknya sebagai Penpres yang dianggap inkonstitusional, secara sosiologis dianggap memberikan citra buruk tentang sistem politik di Indonesia dan secara politis Undang-Undang tersebut dianggap mencerminkan keadaan darurat mengingat kedudukannya sebagai Penpres ketika diundangkan. (Edi Setiadi dan Dian Andriasari, 2013:9)

Untuk itulah penyisipan pasal-pasal delik ideologi setelah dicabutnya Undang-Undang subversif harus memenuhi 3 unsur sekaligus, yaitu:

1. Bertentangan dengan hukum

2. Harus ada akibat yang menimbulkan keonaran

3. Dilakukan didepan umum.

Jadi tidak cukup menurut penulis bila memang penerapan pidana tutupan sebagai pengganti pidana penjara hanya dikaitkan dengan tindak pidana politik saja. Walaupun diketahui bersama yang paling relevan pada era saat ini untuk diterapkan apabila terjadi suatu peristiwa dalam hal mengancam keamanan negara yang telah dirumuskan dalam KUHPidana saat ini adalah pidana penjara. Namun bila para hakim dapat menggali dan memperluas lagi rumusan mengenai pidana tutupan ini maka akan dapat pula diterapkan kepada para pelaku tindak pidana lainnya dalam hal ini tindak pidana umum, tindak pidana militer dan tindak pidana khusus lainnya terkait dalam hal mengadili orang yang melakukan kejahatan yang diancam dengan pidana penjara, karena terdorong oleh maksud yang patut dihormati, maka hakim boleh menjatuhkan hukuman tutupan.

II. Penerapan Pidana Tutupan Masih Efektif Diberlakukan Dalam Sistematika KUHPidana Indonesia Dikaitkan Masih Ditempatkannya Pidana Tutupan Dalam RUU KUHPidana 
Berdasarkan uraian diatas maka penulis berpendapat efektifitas pelaksanaan dan penerapan pidana tutupan di Indonesia dapat dilihat dalam rumusan Pasal 74 RUU KUHPidana sebagai berikut:

(1) Hakim dapat mengadili orang yang melakukan tindak pidana yang dapat dipidana dengan pidana penjara, dengan mengingat keadaan dan perbuatannya, dapat menjatuhkan pidana tutupan.

(2) Pidana tutupan dapat dijatuhkan kepada terpidana yang melakukan tindak pidana karena terdorong oleh maksud yang patut dihormati.

(3) Ketentuan dalam ayat (2) tidak berlaku apabila cara melakukan atau akibat dari perbuatan itu sedemikian rupa, sehingga hakim berpendapat bahwa pidana penjara lebih tepat.

Sehingga terkait rumusan dalam Pasal 2 UU No. 20 Tahun 1946 tentang Pidana Tutupan, cakupannya lebih luas tidak hanya berorientasi dalam hal delik politik saja sebagai mana penjelasan pada Pasal 74 RUU KUHPidana, namun dapat mencakup unsur tindak pidana umum dan khusus lainnya sehingga baik , jika ditinjau secara makro bahwa hukum pidana dapat diartikan sebagai bagian dari keseluruhan hukum yang berlaku disuatu negara, yang mengadakan dasardasar dan aturan (Edi Setiadi dan Dian Andriasari, 2013 : 18), untuk :

1. Menentukan perbuatan-perbuatan mana yang tidak boleh dilakukan, yang dilarang dengan disertai ancaman atau sanksi yang berupa pidana tertentu seperti dapat dijatuhi pidana tutupan bagi siapa yang melanggar larangan tersebut.

2. Menentukan kapan dan dalam hal-hal apa kepada mereka yang telah melanggar larangan-larangan itu dapat dikenakan atau dijatuhi pidana sebagaimana yang telah diancamkan

3. Menentukan dengan cara bagaimana pengenaan pidana itu dapat dilaksanakan apabila ada orang yang disangka telah melanggar larangan itu.

Di era saat ini, munculah pertanyaan, masih adakah tindak pidana dengan mengingat keadaan dan perbuatan seorang dan/atau beberapa petindak karena terdorong oleh maksud yang patut dihormati, mengingat rumusan Pasal 74 RUU KUHPidana tersebut di atas, hal ini terkait dengan Ancaman Keamanan Negara. 
Penulis berpendapat penerapan pidana tutupan akan menjadi tidak efektif lagi dilaksanakan diera saat ini bila dikaitkan dengan apa yang sudah kita bahas dalam bahasan sebelumnya terkait yuriprudensi peristiwa 3 Juli 1946 karena pidana tutupan ini hanya akan menjadikan suatu kepentingan politik tertentu bagi beberapa golongan atau penguasa dalam melakukan suatu pembenaran atas tindak pidana tersebut, padahal semua unsur tindak pidana telah memenuhi syarat namun akibat adanya kepentingan suatu politik tertentu pidana pokok ini dapat diterapkan oleh hakim dalam menjatuhkan putusan.

Masih ada celah kelemahan yang dapat dimanfaatkan oleh sebagian pihak dengan mengatasnamakan tujuan mulia dengan maksud yang patut dihormati demi sebuah pertemanan. Akan menjadi lebih efektif bila pidana tutupan ini diterapkan dalam hal berlaku bagi semua para pelaku tindak pidana bahkan terhadap pelaku tindak pidana anak anak dibawah umur mengingat anak-anak dalam usia ini adalah belum memiliki suatu pertimbangan, pemikiran atas perbuatan dan tindakan yang dilakukan dimana telah disebutkan dalam Pasal 99 ayat (1) ke-4 RUU KUHPidana sehingga dapatlah dikatakan tindakan mereka (anak-anak dibawah umur) dengan mengingat keadaan dan perbuatannya dapat dijatuhkan pidana tutupan, bukan atas dasar maksud yang patut dihormati karena akan sangat sulit diera saat ini bagi petindak khususnya mengancam keamanan negara memiliki maksud tersebut.

Adapun beberapa faktor penghambat penerapan dan pelaksanaan pidana tutupan saat ini adalah:

i. Disparitas pemidanaan di era Globalisasi

Disparitas pemidanaan menjadi pertanyaan utama yang berkaitan erat dengan pertanyaan apakah suatu putusan hakim sudah memenuhi rasa keadilan. Masalah disparitas pemidanaan muncul apabila membandingkan penjatuhan sanksi pidana satu putusan hakim dengan putusan hakim lainnya. Makna disparitas pemidanaan akan tercemin dari putusan pidana yang dijatuhkan oleh hakim atas pelanggaran hukum yang sama.

Adapun terkait perbuatan pidana (dalam Edi Setiadi dan Dian Andriasari, 2013 : 62), terdapat dua aliran yaitu aliran monistis dan aliran dualistis. 
Moeljanto menganut pandangan dualistis yaitu pengertian perbuatan pidana tidak meliputi pertanggungjawaban pidana, Moeljanto membedakan dengan tegas dapat dipidananya perbuatan dan dapat dipidana orangnya dan Moeljanto memisahkan pengertian perbuatan pidana dan pertanggungjawaban pidana. Sedang pandangan monistis melihat keseluruhan syarat untuk adanya pidana itu kesemuanya merupakan sifat dari perbuatan. Jadi untuk adanya suatu perbuatan pidana menurut Moeljatno harus ada unsur: Perbuatan manusia, memenuhi rumusan undang-undang dan melawan hukum.

ii. Dilema Dalam Penjatuhan Pidana Tutupan

Sekilas lintas orang akan mengira bahwa masalah pemberian pidana itu hanya merupakan persoalan Hakim belaka. Bila yang diartikan sebagai pidana itu hanya apa yang tercantum dalam pasal 10 KUHP dalam hal tindak pidana umum dan pasal 6 KUHPM dalam hal tindak pidana Militer, maka pemberian pidana hanya bersangkut-paut dengan para Hakim saja, tetapi ini pun tidaklah benar seluruhnya. Misalkan dalam keputusan tentang pidana penjara Hakim hanya memutuskan dan menentukan batas-batas belaka saja, sejak cara pelaksanaan pidana itu tergantung dari pihak lembaga pemasyarakatan dan juga kemungkinan untuk membebaskan secara bersyarat adalah wewenang dari Menteri Kehakiman dan pandangan bahwa pidana di Indonesia harus bersumber dan oleh karenanya harus berdasarkan Pancasila tidak perlu dipersoalkan lagi kendatipun pandangan demikian dinyatakan secara umum saja. In Concreto, masih diperlukan penganalisisan dan penjelasan lebih lanjut. Contoh yang sangat peka dan "frapant" dalam hal ini, misalnya pidana tutupan (Kadri Husin dan Budi Rizki Husin, 2016 : 16). Sering dilupakan juga oleh para penegak hukum, terutama oleh para hakim.

Maka dapat penulis katakan, bahwa pelaksanaan dan penerapan pidana tutupan saat ini, terkait banyaknya ketentuan-ketentuan pidana baik di dalam maupun di luar KUHPidana yang harus direvisi menyadarkan kita, bahwa ternyata sampai saat ini bangsa Indonesia belum memiliki KUHPidana yang 
bersifat Nasional, kalaupun telah terjadi beberapa perubahan hal ini bukan merupakan pembaharuan hukum pidana tetapi hanya merupakan penyesuaian dengan keadaan yang berkembang saat ini. Sehingga terkait rumusan daripada Pasal 2 UU No. 20 Tahun 1946 tentang Pidana Tutupan dapat lebih luas cakupannya tidak hanya berorientasi dalam hal delik politik saja sebagai mana penjelasan pada Pasal 74 RUU KUHPidana namun dapat mencakup unsur tindak pidana umum dan khusus lainnya sehingga ditinjau secara makro bahwa hukum pidana dapat diartikan sebagai bagian dari keseluruhan hukum yang berlaku disuatu negara, yang mengadakan dasar-dasar dan aturan untuk: (Edi Setiadi dan Dian Andriasari, 2013:18)

1. Menentukan perbuatan-perbuatan mana yang tidak boleh dilakukan, yang dilarang dengan disertai ancaman atau sanksi yang berupa pidana tertentu seperti dapat dijatuhi pidana tutupan bagi siapa yang melanggar larangan tersebut.

2. Menentukan kapan dan dalam hal-hal apa kepada mereka yang telah melanggar larangan-larangan itu dapat dikenakan atau dijatuhi pidana sebagaimana yang telah diancamkan

3. Menentukan dengan cara bagaimana pengenaan pidana itu dapat dilaksanakan apabila ada orang yang disangka telah melanggar larangan itu.

Masalah kebebasan hakim dalam memutuskan perkara pidana yang ditanganinya menjadi faktor dapat menimbulkan terjadinya disparitas pemidanaan. Di Indonesia asas kebebasan hakim dalam memutuskan suatu perkara (judicial discretionary power) dijamin sepenuhnya oleh negara, karena hal ini telah diatur dalam Pasal 1 UU No. 48 tahun 2009 tentang Kekuasaan Kehakiman. Dimana kekuasaan kehakiman memiliki kekuasaan yang merdeka dalam melaksanakan proses peradilan guna untuk menegakkan hukum yang berkeadilan berdasarkan Pancasila dan UUD Negara RI 1945 (Undang-Undang Republik Indonesia Nomor 48 Tahun 2009 tentang Kekuasaan Kehakiman), dengan demikian terselenggaranya maka dapat dikatakan Republik Indonesia adalah Negara Hukum. Sehingga dapat dikatakan bahwa Hakim sebagai 
penyelenggara kekuasaan kehakiman memperoleh kewenangan untuk memeriksa dan memutus perkara pidana yang ditanganinya secara bebas tanpa intervensi dari pihak manapun.

Namun perlu penulis ingatkan bahwa kebebasan hakim bukanlah tanpa batas dalam hal menjatuhkan putusan atau sanksi pidana. Di mana terkait asas Nulla Poena Sine Lege hakim hanya dapat memutus berdasarkan jenis dan berat sanksi sesuai yang diatur dalam Undang-Undang. Adapun pasal terkait asas legalitas diatur dalam Pasal 1 ayat (1) KUHP, dalam jenis pidana tutupan misalnya diatur dalam pasal 2 ayat (1) UU No. 20 tahun 1946 disebutkan bahwa dalam mengadili orang yang melakukan kejahatan, yang diancam dengan hukuman penjara, karena terdorong oleh maksud yang patut dihormati, hakim boleh menjatuhkan hukuman tutupan. Juga disebutkan dalam Pasal 5 ayat (1) UU No. 20 tahun 1946 bahwa tempat untuk menjalani hukuman tutupan, cara melakukan hukuman itu dan segala sesuatu yang perlu untuk menjalankan undang-undang ini diatur dalam peraturan pemerintah yang diatur dcoroalam Peraturan Pemerintah Nomor 8 tahun 1948 tentang Rumah Tutupan. (UndangUndang Republik Indonesia Nomor 20 Tahun 1946 tentang Hukuman Tutupan) Dalam kenyataannya tidak pernah sampai dengan sekarang ini hakim yang menjatuhkan pidana tutupan.

\section{Penutup}

\section{A. Kesimpulan.}

1. Bagi pelaku tindak pidana akan lebih relevan bila penerapan pidana tutupan diterapkan sebagai pengganti Pidana penjara diera saat ini bukan hanya sebatas tindak pidana politik saja khususnya berkaitan dengan ancaman keamanan negara namun juga dapat diterapkan kepada seluruh pelaku tindak pidana mengingat perbuatan dan bagaimana cara melakukan tindak pidana tersebut.

2. Pidana tutupan dalam RUU KUHPidana bisa menjadi salah satu alternatif pemberian hukuman kepada narapidana khsusnya kepada narapidana anak, dalam hal ini peneliti menilai lebih efektif diterapkan 
kepada anak-anak dibawah umur mengingat keadaan dan perbuatannya dibandingkan terhadap orang dewasa yang telah dinyatakan dalam Undang-undang terkait dengan maksud yang patut dihormati akan tetapi bila para hakim dapat menggali lebih jauh lagi maka kemungkinan itu dapat dilakukan penjatuhan pidana tutupan kepada pelaku tindak pidana lainnya baik itu pidana umum, militer dan pidana khusus lainnya mengingat dasar hukum daripada pidana tutupan ini masih berlaku sampai dengan sekarang ini.

\section{B. Saran}

1. Perlu adanya revisi terhadap KUHPidana khususnya berkaitan dengan Pidana tutupan.

2. Perlu adanya peninjauan kembali terhadap RUU KUHPidana khususnya pasal 74 mengenai penerapan pidana tutupan yang dijatuhkan kepada terpidana karena terdorong maksud yang patut dihormati hanya terhadap pelaku tindak pidana politik saja, namun selayaknya dapat diterapkan kepada pelaku tindak pidana lainnya mengingat cara dan bagaimana perbuatan tindak pidana itu dilakukan.

\section{Daftar Pustaka}

Sianturi, S.R. Hukum Penitensia di Indonesia. Jakarta: Pusat Studi Hukum Militer Sekolah Tinggi Hukum Militer AHM-PTHM, 2013.

Setiadi, Edi dan Dian Andriasari. Perkembangan Hukum Pidana di Indonesia. Yogyakarta: Graha Ilmu. 2013.

Husin, Kadri dan Budi Rizki Husin. Sistem Peradilan Pidana Di Indonesia. Cet.1. Jakarta: Sinar Grafika. 2016.

Republik Indonesia. Undang-Undang Nomor 1 Tahun 1946 Tentang Peraturan Hukum Pidana. , Undang-Undang Nomor 73 Tahun 1958 tentang Menyatakan

Berlakunya Undang-Undang No. 1 Tahun 1946 Republik Indonesia Tentang Peraturan Hukum Pidana Untuk Seluruh Wilayah Republik 
Indonesia dan Mengubah Kitab Undang-Undang Hukum Pidana. Lembaran Negara Tahun Nomor 127 Tahun 1958. Tambahan Lembaran Negara Nomor 1660. , Undang-Undang Nomor 39 Tahun 1947 tentang Menyesuaikan

Hukum Pidana Tentara (Staatsblad 1934, No. 167) Dengan Keadaan Sekarang. , Undang-Undang Nomor 20 Tahun 1946 tentang Hukuman Tutupan. Berita RI No II. , Undang-Undang Nomor 48 Tahun 2009 tentang Kekuasaan

Kehakiman. Lembaran Negara Tahun Nomor 157 Tahun 2009. Tambahan Lembaran Negara Nomor 5076. Peraturan Pemerintah Nomor 8 Tahun 1948 tentang Rumah Tutupan. , RUU tentang Kitab Undang-Undang Hukum Pidana 2019.

Setyawan, Eko Huda. "Eksekutor Cebongan: Setelah Tembak 4 Tahanan, Saya Gemetar" (https://www.liputan6.com/news/read/641013/eksekutor-cebo ngan-setelah-tembak-4-tahanan-saya-gemetar), diakses Januari 2020.

Divonis, "Kopassus Penyerang Lapas Cebongan Panen Dukungan" (https://www.liputan6.com/news/read/684206/divonis-kopassus-penyera ng-lapas-cebongan-panen-dukungan), diakses Januari 2020.

Irawan, Yohanes Kurnia. "Akhir Perjuangan Suami yang Obati Istrinya dengan Ganja, Fidelis Bebas dari Penjara” (https://regional.kompas. com/read/2017/11/16/14505631/akhir-perjuangan-suami-yang-obati-ist rinya-dengan-ganja-fidelis-bebas-dari), diakses Januari 2020. 